\title{
1 Ambivalências
}

\author{
CORPOS QUE SURRAM E SÃO SURRADOS: VIOLÊNCIA E CULTURA \\ BRASILEIRA EM O GRANDE MENTECAPTO, DE FERNANDO SABINO \\ BODIES THAT HIT AND ARE HIT: VIOLENCE AND BRAZILIAN CULTURE \\ IN $O$ GRANDE MENTECAPTO, BY FERNANDO SABINO \\ CUERPOS QUE GOLPEAN Y SON GOLPEADOS: VIOLENCIA Y CULTURA \\ BRASILEÑA EN O GRANDE MENTECAPTO, POR FERNANDO SABINO
}

\begin{abstract}
RESUMO
Analisaremos o romance $O$ grande mentecapto: relato das aventuras e desventuras de Viramundo e de suas inenarráveis peregrinações (1979), de Fernando Sabino. 0 objetivo deste artigo é demonstrar algumas das várias faces da violência na cultura brasileira. Através da narrativa literária, perceberemos que as violências, no Brasil, são operadas contra determinados grupos sociais, historicamente invisibilizados e sistematicamente violentados desde os primórdios da nação. Se o método de análise literária é de recorte sociológico, a consideração final conduz-nos à multiplicidade de violências do Brasil e que podem e eventualmente devem ser modificadas, a partir da consciência e engajamento propiciados pela narrativa literária em questão.
\end{abstract}

Palavras-chave: Violência. nação. 0 Grande Mentecapto.

\footnotetext{
${ }^{1}$ Licenciado em Letras Português (2008), Especialista em Filosofia e Literatura (2013) e Mestre em Letras - Estudos Literários (2015) pela Universidade Federal de Sergipe. E-mail: hofaragao1@gmail.com.
} 


\begin{abstract}
We will analyze the novel $O$ grande mentecapto: relato das aventuras e desventuras de Viramundo e de suas inenarráveis peregrinações (1979), written by Fernando Sabino. This paper aims to demonstrate some of the many faces of the violence in the Brazilian culture. Through the literary narrative, we will perceive that the violences, in Brazil, are operated against determined groups, made historically invisible and systematically violented since the beginning of the nation. If the literary analysis method is sociological, the last considerations lead us to the multiple violences in the Brazil and eventually we must modify them, from the awareness provided by the literary narrative in study.
\end{abstract}

Keywords: Violence. Nation. 0 grande Mentecapto.

\title{
RESUMEN
}

Analizaremos la novela $O$ grande mentecapto: relato das aventuras e desventuras de Viramundo e de suas inenarráveis peregrinações (1979), por Fernando Sabino. El objetivo de este artículo es mostrar algunas de las diversas caras de la violencia en la cultura brasileña. A través de la narrativa literaria, nos daremos cuenta de que la violencia, en Brasil, es operada contra ciertos grupos sociales, históricamente invisibilizados y sistemáticamente violados desde el inicio de la nación. Si el método de análisis literario es sociológico, la consideración final nos lleva a la multiplicidad de violencias en Brasil que pueden y eventualmente deben ser modificadas, a partir de la conciencia y el compromiso proporcionados por la narrativa literaria en cuestión.

Palabras clave: Violência. Nación. 0 grande Mentecapto. 


\section{Introdução}

Enquanto autor literário, Fernando Sabino iniciou a carreira como autor de histórias curtas. Em 1956, é lançado O Encontro Marcado, o romance que vai colocá-lo nas principais obras de História da Literatura brasileira. Muitos anos depois, em 1979, vem a público o segundo romance, $O$ Grande Mentecapto: relato das aventuras e desventuras de Viramundo e de suas inenarráveis peregrinações. Em termos de "nação", a discussão ganha tons muito diferentes, se compararmos as produções:

[Vítor] — Você ainda é católico?

[Eduardo Marciano] - Eu nunca lhe disse que era católico.

[Vítor]- Qual, vocês mineiros são todos católicos [...] (SABINO, 1996, p. 249).

Em ambas as narrativas, a união nacional é religiosa - digo nacional por subtração, pois Geraldo Viramundo, assim como Eduardo Marciano, protagonistas dos romances em tela, "sendo o mineiro, é o brasileiro, o povo brasileiro" (AMADO, 1996, p. 70). Entretanto, o tom político do catolicismo é quase antagônico, nas produções aludidas. Do mesmo modo procedo a pensar em relação a primeiro e segundo romances: na falta de uma característica nacional homogênea mais forte, escolheu-se a religião: 0 catolicismo. A particularidade está em que, na segunda narrativa romanesca, o autor escolheu uma perspectiva mais cruel, embora ainda embebida de catolicismo (o que faz parte de toda a produção de Fernando Sabino), logo, escolheu-se a violência como módulo identificador do brasileiro - ou pelo menos parece ser este o primeiro vetor de interpretação da cultura brasileira em 0 Grande Mentecapto (1979).

O herói que se aventura no segundo romance do mineiro Fernando Sabino é animado pela figura do herói destituído de trabalho, do herói louco - e porque não faz parte do círculo lar-família-trabalho deve ser considerado socialmente louco e/ou malandro:

Não é à toa que o nosso panteão de heróis oscila entre uma imagem deificada do malandro (aquele que vive na rua sem trabalhar e ganha o máximo com um mínimo de esforço), o renunciador ou o santo (aquele que abandona o trabalho neste e deste mundo e vai trabalhar para o 
outro, como fazem os santos e os líderes religiosos) [...] (DAMATTA, 1998, p. 31).

A história de $O$ Grande Mentecapto (1979) é a biografia de um rapaz, Geraldo Boaventura, que enlouquece após defender a viúva Pietrolina do apedrejamento. Após isso, ele passa a palmilhar as longas estradas de Minas Gerais. Neste processo, ele conhece outros seres desviantes em relação ao status quo, apontando forças dos mais "fracos" e vícios dos mais "fortes", o que relembra bastante o tom das narrativas picarescas espanholas do século XVI e XVII.

Ao final da narrativa, Geraldo Viramundo (ele assume este nome, a partir do processo de loucura) é o líder de uma revolução, alocada na Praça da Liberdade. A fim de analisar processos de violência e cultura nacional, tenhamos a seguinte passagem literária como glosa: Informaram ao Governador de Minas: "E tem um possesso chamado Viramundo que assumiu o comando de tudo isso. É uma espécie de Antônio Conselheiro. Acho que teremos em Minas um novo Canudos" (SABINO, 1995, p. 214). Em Canudos, a lógica era do líder religioso e, em O Grande Mentecapto (1979), as forças do Estado vão se abater sobre o (anti-)heroísmo, a picardia/malandragem de um homem sem ligações com o mercado de trabalho ou com políticos, em contestação, junto a uma multidão de injustiçados. Ambos (Antônio Conselheiro e Geraldo Viramundo) representam a vida violentada até o último suspiro, conforme se pratica correntemente na cultura brasileira.

\section{Violência histórica (a colonização, o patriarcado, a escravidão) e hábitos culturais}

Quando analisa um conto de Guimarães Rosa, "Famigerado", percentente ao livro Tutaméia (1967), José Miguel Wisnik (s.d.) discorre brevemente sobre o que se denominaria "violência endêmica" no Brasil. 0 músico e crítico literário se referia ao que ocorre no interior do Brasil, entre os jagunços (e no nordeste, diríamos, o que ocorreu entre os cangaceiros), mas também ao que ocorre nas cidades: a violência da polícia, os 
pequenos furtos dos "moleques", entre muitas outras violências que ocorrem cotidianamente. Não pretendo, neste artigo, esboçar qualquer comparação com $O$ Grande mentecapto: relato das aventuras e desventuras de Viramundo e de suas inenarráveis peregrinações (1979) só pelo fato de o romance de Fernando Sabino ter sido publicado em época próxima. Muito antes, será mostrado um passado histórico em que, no bojo da colonização de um sistema patriarcal e escravocrata, realizou-se a violenta nação Brasil.

Se levarmos em consideração as palavras de Luiz Felipe Alencastro, historiador contemporâneo, entenderemos como podemos chamar de "nacional" o caráter violento da nossa sociedade. Nosso passado nos forma, conforma tradições e nos assenta em hediondas "surras", seja na época dos senhores de engenho ou já no século XX: "Método de terror luso-brasílico, e mais tarde autenticamente nacional, brasileiro, o choque do bárbaro arbítrio do senhor - visando demonstrar ao recém-chegado seu novo estatuto subumano - voltou a ser praticado durante a ditadura de 1964-85" (ALENCASTRO, 2000, p. 148). Antes era o senhor de terras, de escravos; hoje em dia é a polícia e os políticos: em suma, a violência é parte característica da formação cultural brasileira.

Para irmos ainda mais longe, temos que considerar o "democrático" solo em que pisamos: somos ou não somos uma democracia? Uma "democracia racial", visto que somos a união das três raças: negros (africanos), índios (americanos) e brancos (europeus)? A mestiçagem parece ser importante característica brasileira, para variados nomes do pensamento social brasileiro, de modo que destacamos uma citação sintomática: “A mestiçagem, que é o signo sob o qual se forma a nação brasileira, e que constitui sem dúvida o seu traço característico mais profundo e notável [...]" (PRADO JR., 1994, p. 96). Sabemos que não tratamos igual a todos, desde os remotos tempos da colonização e escravidão: não é à toa que Gilberto Freyre (2006) tende a ver no índio um preguiçoso e Luiz Felipe de Alencastro (2000) denuncia com tanta veemência as torturas sofridas pelos negros em tempos de escravidão. Menos à toa é $O$ negro no mundo dos brancos (2007), em que Florestan Fernandes é explícito: democracia racial é um mito que deve ser combatido, pois há o preconceito velado. A questão norteadora que, em termos de violência racial, impera, é: “[...] o que é mais importante para o 'negro' e o 'mestiço': uma consideração 
ambígua e disfarçada ou uma condição real de ser humano econômica, social e culturalmente igual aos brancos?" (p. 39, grifos do autor).

Se considerarmos aceito que, por razões históricas, a violência se espalha indefinidamente em nosso país contra grupos minoritários, podemos trabalhar mais diretamente estas questões, primeiro em termos históricos, depois em termos literários. Lançamos mão da hipótese de que todo processo colonizador tende a ser extremamente violento. Apaga-se a cultura autóctone (em nosso caso, a cultura ameríndia) e, através de variadas estratégias de violência, são impostos novos hábitos culturais - pelo menos este seria o "ganho" de uma sociedade culturalmente híbrida.

Não é só Gilberto Freyre (2006), mas também Sérgio Buarque de Holanda (2013), quem vê o Brasil como um lugar em que pesaram dois importantes fatores: aclimatação e desenvolvimento econômico. Da aclimatação, em linhas gerais, percebe-se que o português, tão movediço em termos de grandes navegações, criou-se um povo colonizador, tanto em África como no Brasil. Do desenvolvimento econômico, ocorrido através da plantação de cana-de-açúcar, num primeiro momento, criou-se uma forte lavoura em regime de monocultura. Em última instância, para colonizar, povoar e crescer economicamente, precisava-se de braços índios e negros para trabalhar: talvez apenas pudéssemos, de fato, sermos signatários de um sistema violentamente patriarcal.

Em termos literários, repita-se que, se ainda estamos em linhas introdutórias, precisamos ter o cuidado de, ao demonstrarmos representações da violência, não acreditarmos que são as representações que o autor gostaria de reforçar ou ver na vida real. É mais crível trabalharmos com a hipótese de que são um retrato documental da naturalização da violência contra tipos humanos social e historicamente marginalizados. Um exemplo muito simples se dá ainda no início do romance, apenas para sermos ilustrativos, de uma discussão de crianças:

João Molenga fez logo cara de choro.

- Tá bem, seu fresco, eu aceito: não é preciso chorar não.

Naná, o mais velho de todos, se adiantou:

- Não chama ele de fresco não, que ele é meu irmão. 
- Merda pra você e pra ele.

A importância de Geraldo atingiu o auge naquele momento. Ninguém nunca tinha mandado Naná à merda sem ir também logo em seguida, e depois de apanhar na cara (SABINO, 1995, p. 18-19).

Há efetivas dúvidas se é melhor tratarmos primeiro da violência simbólica, chamar um menino de "fresco", em clara alusão homofóbica, ainda tão típica em nosso país, ou a própria surra que o garoto Naná costumeiramente dava em seus amigos. 0 importante, aqui, é demonstrarmos, ainda que em linhas gerais, a naturalização da violência. Somos violentos desde pequenos: não se trata de reforçarmos a homofobia ou de respeitarmos os mais velhos, mas é questão de uso do corpo, pela mão fechada para o soco, e da diplomacia: somos considerados um povo sem guerras, mas violentamos, diariamente, nossos iguais, tornando-os, por variados motivos (inclusive raciais ${ }^{2}$, econômicos, de gênero, sexualidades, etc.), seres inferiores.

Muito mais proveitoso seria tratarmos logo de apresentar o nosso protagonista, que prefere que o chamem José Geraldo Peres da Nóbrega e Silva, mas nasceu Geraldo Boaventura e ficou famoso nas Minas Gerais com o nome de Geraldo Viramundo. Nascido na cidade de Rio Acima, é filho de pai português e mãe italiana (dona Nina):

Seu pai, um português, tinha vindo para o Brasil em 189***, na primeira leva de imigrantes que sucedeu ao decreto de nova política imigratória da República recém proclamada, e se casou no Rio com uma italiana naquele mesmo ano. Como ele foi acabar morando em Rio Acima, só Deus sabe (SABINO, 1995, p. 9).

[...] no momento em que a sociedade brasileira sofre transformações profundas, passando de uma economia escravista para outra de tipo capitalista, de uma organização monárquica para republicana, e que se busca, por exemplo, resolver o problema da mão-de-obra incentivandose a imigração europeia (ORTIZ, 2012, p. 38).

Esse será, aliás, um dos fatores que vão tolher o trato inter-regional de escravos entre o Norte e o Centro-Sul, duzentos anos mais tarde, depois de 1850, no Império, quando cessa o tráfico negreiro oceânico: reputados rebeldes, os escravos "ladinos" vendidos pelas províncias do Norte são mal aceitos pelos fazendeiros do café do Centro-Sul, acelerando o

\footnotetext{
2 Parece-nos significativa a fala em que o personagem principal ganha uma aposta e prescinde do prêmio, bolinhas de gude: "Toma, negrada! Não quero aposta nem nada! Quantas bolas quiserem! Todas, todas! Parou, vocês viram? Eu disse que parava! [o trem]" (SABINO, 1995, p. 21).
} 
movimento em favor da imigração europeia (ALENCASTRO, 2000, p. 146).

Todos os indícios demonstram o que significa a chegada dos europeus no Brasil, naqueles tempos de início de República, em termos de raça e comércio (negávamos o ex-escravo e importávamos os europeus). Filho de um português comerciante (possuía uma venda, chamada "Armazém Boaventura - Secos e Molhados"), para fazer jus ao espírito mercantilista lusitano, conforme atestam Gilberto Freyre (2006) e Sérgio Buarque de Holanda (2013), e de uma italiana, Geraldo Boaventura crescerá conforme os princípios daquele tempo: devemos importar europeus para branquear a espécie. Mais importante que a política imigratória, em nossa narrativa, é a loucura de Geraldo Boaventura/Geraldo Viramundo (a mudança de nome e a perda da identidade é sintoma de tal insanidade): após passar algum tempo como aspirante a clérigo católico, isto é, após largar o seminário, decide defender a viúva Pietrolina, é atingido por uma pedra e "decide" percorrer todo o território mineiro a pé. Torna-se um andarilho. Recusa, em sua "demência progressiva" (o termo é de Massaud Moisés, 2001, p. 391), o lar da família. A partir do processo de perda razão instrumental, por assim dizer, o protagonista anda por todo o território mineiro, dialogando com os mais variados tipos sociais, em debandada loucura, o que nos provoca a comicidade e nos faz entrever, nos meandros da narração, agudo uso da ironia.

Se voltarmos à formação cultural de Geraldo Boaventura (mais tarde se chamará, repetimos, Geraldo Viramundo), veremos que cresceu no interior, no sertão: "(Corria em Rio Acima que ele [Boaventura, o pai] viera para o sertão de Minas com a mulher, fugindo das autoridades imigratórias [...]" (SABINO, 1995, p. 10), o que significa que teremos um personagem sem grandes interdições sociais, já que o espaço em que ele vive representa o ambiente social em que não há força do sistema judiciário e por isso mesmo é utilizado para pessoas que fogem das autoridades: "O sertão oferece a liberdade, o afastamento de uma autoridade incômoda e pesada" (PRADO JR., 1994, p. 112). Um menino herói, que conseguiu parar o trem na cidade de Rio Acima, é ainda Geraldo Boaventura, que conseguiu fazer o que ninguém conseguia. No sertão, a modernidade do trem-de-ferro era, antes da existência de nosso (anti-)herói (que conseguira fazer a ação de parar o trem) apenas para ser vista de longe. 
Da visão à realidade, temos o crescimento urbano do Brasil, que não se limita, certamente, ao traçado das grandes cidades, tal como Rio de Janeiro, São Paulo ou Belo Horizonte. Em verdade, a repercussão da urbanidade chegou ao sertão. Desta relação entre sertão e cidade, fez-se igualmente o Brasil:

No Brasil, onde imperou, desde tempos remotos, o tipo primitivo da família patriarcal, o desenvolvimento da urbanização - que não resulta unicamente do crescimento das cidades, mas também do crescimento dos meios de comunicação, atraindo vastas áreas rurais para a esfera de influência das cidades - ia acarretar um desequilíbrio social, cujos efeitos permanecem vivos até hoje (HOLANDA, 2013, p. 145).

Construída junto a uma simples picada (o pai não tinha ainda seu negocinho, e trabalhava na olaria), a casinha acabou ficando com a estrada à sua porta. Por um triz os engenheiros com seus traçados e mapas não levaram de cambulhada com árvores, pedras e barrancos a morada do Boaventura. [...] De tal maneira ficou sendo a estrada parte integrante da casa, que a filharada do casal cresceu toda no meio dela. Um dos filhos, dizem que quase nasceu na estrada, quando dona Nina, já no nono mês, sucumbiu ao peso de um feixe de lenha; outro, contudo, o mais velho, é certo que foi gerado ali, exatamente junto à curva, quando nem casa nem estrada havia. No princípio só passavam por ela carros de boi e outras vagarosas viaturas de tração animal, que de longe se avistavam, dando sinal de alarme e pedindo passagem. Mas logo começaram a trafegar os primeiros automóveis, e os meninos fugiam como galinhas, para voltar em seguida (SABINO, 1995, p. 10-11).

O polo de criação industrial devora todo o espaço circundante, oferecendo, deste modo, um novo estilo de vida aos cidadãos. Geraldo Viramundo é aquele que parou o trem (SABINO, 1995, p. 19-ss.), mas é também aquele que ainda preserva, na infância, seus costumes tradicionais. Mesmo que depois Geraldo Viramundo percorra as cidades de Minas Gerais, em marcha revolucionária, com prostitutas, cegos e mendigos, isto é, tipos marginais da sociedade brasileira, até chegarem todos (os loucos como Viramundo e os seus próximos) a Belo Horizonte, passando por Mariana, Ouro Preto, Juiz de Fora, entre várias outras cidades, ainda na infância ele se deleita com o famoso costume indígena:

Em contraste com tudo isso é que surpreendeu aos primeiros portugueses e franceses chegados nesta parte da América um povo ao que parece sem mancha de sífilis na pele; e cuja maior delícia era o banho de rio (FREYRE, 2006, p. 182). 
Sei só que Geraldo, mal acabava a aula na escola, saía correndo feito doido em direção ao rio, do outro lado da cidade (SABINO, 1995, p. 13).

Se já demonstramos brevemente a violência como recurso histórico e naturalizado de nossa cultura, o momento político da chegada dos pais do nosso protagonista, a relação deste com a modernidade e alguns hábitos tradicionais mantidos por meninos do sertão brasileiro, cumpre-nos ainda evocar a revolução de párias empreendida por Geraldo Viramundo. Conforme atesta Wilson Martins (1995) ${ }^{3}$, romances como O Grande Mentecapto (1979), pelo uso desenfreado da comicidade, promete um tom político, mas "só" entrega ao leitor um deleite carnavalizado. Entretanto, Gilberto Freyre (2006) analisa as tensões políticas brasileiras conforme diapasão diferente:

Estes são movimentos à parte, de um profundo sentido social, como à parte o é o de Canudos - resultado da diferenciação da cultura que se operou entre o litoral e o sertão. Os relapsos em furor selvagem observamo-los em movimentos de fins aparentemente políticos ou cívicos, mas na verdade pretexto de regressão à cultura primitiva, recalcada, porém não destruída (FREYRE, 2006, p. 213).

O famoso sociólogo pernambucano, com esta última citação, encara o Brasil como lugar carnavalizado, em termos de política. Nossas revoluções não têm o ideário, mas apenas a flama, o estopim de preocupação cívica, mas não o preparo filosófico para que as questões de ordem política alce à categoria de reivindicação social. Em verdade, o que ocorre é diverso: há uma elite política que, pelas vias do discurso, descaracteriza e oprime o discurso político das classes subalternas, pois não nos parece inferior o discurso satírico, frente ao discurso oficial, isto é, por que seriam as classes subalternas obrigadas a usar a lógica de sentido, a linguagem, dos advogados e políticos, dos empresários e "engravatados"? Como chamariam atenção para o fato de serem diferentes, caso os populares se ocultassem na linguagem dos chefes políticos? É evidente que não estamos, pelas vias da carnavalização, a voltar a processos psíquicos primitivos, mas demarcando um espaço sócio-político, no âmbito da literatura.

\footnotetext{
3 "Paralelamente às tentativas de romance político (frustradas pelo ingrediente de polêmica peripecial e subjetiva que os esterilizou no plano da criação estilística), podemos contar a ficção deliberadamente satírica, como 0 grande mentecapto, de Fernando Sabino, e Farda, fardão, camisola de dormir, de Jorge Amado" (MARTINS, 1995, p. 241).
} 
Tal caracterização do popular nos lembra o problema da narrativa picaresca. É fato que o romance que ora analisamos possui sua vinculação com o romance espanhol do século XVI e início do século seguinte (Lazarillo de Tormes, El ingenioso hidalgo Don Quijote de la Mancha, entre outros). Neste tipo de romance abundam tipos populares e sempre são violentados, sempre saem "alquebrados" das relações com os poderosos. É Mario Gonzalez (1994) quem vê a "neopicaresca brasileira" - o que inclui romances como $O$ Grande Mentecapto (1979) - como um meio utópico para a denúncia das efetivas injustiças sociais brasileiras, buscando neste tipo marginal, o pícaro, um meio de salvaguardar a nação de tais iniquidades. Ressaltamos que, a despeito de querelas terminológicas, Antonio Candido (2004) vê na mesma possibilidade de representação literária do tipo marginal uma espécie de compensação representativa das mazelas sociais: seria então a malandragem uma estratégia de sobrevivência (o que corresponderia, em certo sentido, à picardia) dos tipos culturalmente desvalorizados - ou estruturalmente destituídos de posição social - de nossa sociedade.

\section{Violências cruzadas: o louco que promete um cartório}

0 governador das Minas Gerais, neste romance, chama-se Clarimundo Ladisbão. Tinha o seu barbeiro oficial, Alberico Pomada. 0 homem das tesouras era alguém em quem o mandatário político tinha confiança, mas ele tinha o péssimo hábito de embriagar-se entre botequins, o que acabou gerando uma internação no hospício. Longe de querer demonstrar, neste momento, a violência engendrada contra usuários de substâncias alteradoras do sistema psíquico, ou de demonstrarmos, pelas internações do protagonista (em dois manicômios e uma prisão), como são retirados à força do sistema social aqueles que pensam diferente, será apenas pontuada uma face "cordial" (HOLANDA, 2013) do brasileiro:

No dia seguinte, já melhorzinho, pediu alta ao enfermeiro, pois tinha de fazer a barba do Governador.

0 enfermeiro achou graça e disse:

- Não posso, porque eu tenho de fazer a do Presidente da República. 
Em vão Alberico Pomada pediu, implorou, esbravejou, ameaçou:

- Eu saio daqui e falo com o Governador para fechar esta merda e botar vocês todos na cadeia, seus animais de rabo!

[...] A partir de então passou a andar triste pelos cantos, correndo o risco de acabar ficando mesmo doido. Depois entrou numa fase em que tentava subornar os enfermeiros:

- Me solta que eu arranjo com o Governador um cartório para você (SABINO, 1995, p. 209-210).

Um pouco mais longe da violência física, das designações pejorativas, das interdições sociais e violências pelas quais loucos passam, temos aqui duas interessantes faces do jogo político brasileiro: a figura daquele que tem contatos influentes e a promessa do cartório. A primeira imagem nos remete ao famoso problema do "sabe com quem você está falando?", em que o contato, a amizade, a cordialidade, estão acima dos interesses comunitários. É a amizade quem fala mais alto, não os procedimentos médicos. É evidente que uma inversão irônica ocorre neste caso, já que, quanto mais arrogante se mostra o pobre barbeiro, mais louco é considerado (e quanto "mais" louco, ele é sujeitado a maiores violências).

A segunda imagem, prometer um cartório, lembra bem os poderes vitalícios que certos grupos de poder detêm. É uma excelente promessa a do Alberico Pomada: se você me soltar, isto é, se dermos um “jeitinho”, posso gratificá-lo, pelas mesmas vias da amizade. A cordialidade se mostra, nesta passagem, em todas as suas faces: da cordialidade como uma força que vem do coração, intempestiva, com seus gritos e ameaças, até a cordialidade que tenta se parecer com amizade, com amenidades, para obter vantagens nas relações de poder (e tais cordialidades são cruzadas: os manicômios "parecem" ser amigos, mas escondem toda uma disciplina forçada, assim como o barbeiro, se parece amigo do povo, enquanto trabalhador, também representa a operação de uma violência simbólica, a da política dos privilégios). 


\title{
3. 0 catolicismo relaxado: a "boa" fé apedreja mulheres
}

É inconteste o caráter relaxado do nosso catolicismo. Desde os tempos coloniais, certamente: "Dançou-se e namorou-se muito nas igrejas coloniais do Brasil" (FREYRE, 2006, p. 327). A nossa melhor representante de tal caráter impudico do nosso catolicismo está na viúva Pietrolina, que costumava ir à missa se confessar:

- É só - repetiu a viúva temerosamente, e acrescentou: - Bem, padre Tibério, há mais, e o pior. Quero lhe pedir um conselho.

- Ahn.

- É a respeito do meu marido. 0 senhor sabe, eu até já tinha esquecido tudo o que se passou, não é? Mas acontece que agora ele começou a me perseguir, o senhor nem imagina. Aparece para mim e me diz coisas, entro no quarto e ele já está lá na cama me esperando. Não aguento mais. E o senhor sabe o que ele quer.

- Ahn.

- Pois é. Ele quer, quer, quer. Não há quem aguente. Me atormenta que só o senhor vendo. 0 pior é que... eu também quero, e um dia eu acabo não resistindo. Como é meu marido, eu pensei... O senhor acha que posso?

$[\ldots]$

- Um seminarista? Então eu me confessei com um seminarista? E o padre Tibério? 0 que é que o senhor está fazendo aí dentro?

Geraldo Viramundo prosseguia, imperturbável:

- ... quer dizer, de duas, uma: ou o seu marido não morreu, e a senhora não tem nada que estranhar ele querer, ou ele morreu mesmo e - que a paz do Senhor seja com ele! - a senhora está querendo fornicar com alguém mais. Os mortos não fornicam, dona Peidolina (SABINO, 1995, p. 40-41)

É igualmente nosso o gosto por fofocas, por palavras de baixo calão, como a quadrinha que se fez em homenagem a esta distinta senhora, que já havia deitado com todos os homens de Mariana, a cidade:

\author{
Mais um marido termina \\ Comprometido ao morrer: \\ Meteu-se com a Peidolina, \\ Morreu de tanto meter (SABINO, 1995, p. 35).
}

A viúva Correia Lopes, a dona Pietrolina, comicamente transformada pelo povo em dona Peidolina, é quem melhor representa a lascívia de nossa moral sexual (e nossa violência contra as mulheres sexualmente livres). 0 marido, mesmo morto, quer fornicar com ela. 
Geraldo Viramundo, no confessionário por engano, ouve toda a confissão da viúva, que não trata, nem de longe, de solilóquios teológicos: ela quer mesmo é resolver os impasses sexuais através da Igreja. 0 nosso Padre Tibério, que momentos antes havia se virado para o próprio Cristo crucificado e "depois de coçar-se por sobre a batina de maneira nada clerical, atravessou de novo a capela em direção à saída" (SABINO, 1995, p. 37-38), é outro bom representante de nossa moral religiosa: jogamos peteca, coçamos as partes íntimas, namoramos às escondidas, em suma, damos todo um colorido à nossa vida religiosa: "E com a imagem de São Gonçalo jogava-se peteca em festas de igreja dos tempos coloniais" (FREYRE, 2006, p. 303).

A violência não deixa de nos aviltar quando apreciamos a existência da viúva Correia Lopes. Ela será linchada publicamente (SABINO, 1995, p. 47-51), como já se sugeriu, porque ela confunde o fantasma do marido com outros homens, logo, qualquer um que traspassasse a janela do quarto da viúva, conseguia relações sexuais com a referida senhora. Uma mulher "fácil" deve ser apedrejada? Esta é, muito hipocritamente, nossa moral sexual. Geraldo Viramundo, um defensor dos injustiçados, vem a ser o único que a defende da ira implacável da comunidade: tanto homens como mulheres a julgam como mulher descartável. A valentia do protagonista custou-lhe a sanidade e, após ser apedrejado, "aos dezoito anos, Geraldo se tornou Viramundo" (SABINO, 1995, p. 51), ou seja, a pedrada que levou na cabeça levou-o à loucura.

Que estamos aqui no topos da mulher adúltera, da Maria Madalena, não há dúvida. Entretanto, deve restar ainda menos dúvida quanto à naturalização da violência que se narra nesta passagem. Uma mulher, em seus desvios mentais, apedrejada. Talvez seja esta a face oculta do bom catolicismo brasileiro: do mesmo modo como se parece caridoso e sexualmente liberal, mostra-se disposto a linchar publicamente todos à sua volta. É a lógica de que, dentro do rito, "eu sou católico", mas, do lado de fora, sou um cidadão em busca de rápidos ganhos comerciais e sexuais (não é que até o prefeito fornicava com a viúva?) e com grande propensão à fofoca e à injúria. Somos todos feitos de aparência, ou, pelo menos, esta é a herança religiosa que recebemos d'Além-mar. 


\section{As casas, a rua e as prostitutas}

A viúva Correia Lopes, há pouco mencionada, consta da biografia de Geraldo Viramundo uma segunda vez. O novo nome é dona Lina. Torna-se uma cafetina, dona de um estabelecimento em que trabalham meretrizes, como Brigite e Marialva, entre outras. Saibamos que os perseguidos deste país não são apenas os "frescos" e os loucos. São as mulheres, especialmente as mulheres de "vida fácil", como se diz. Diariamente estas criaturas, à margem da cultura dominante, são reprimidas, são mandadas para longe do centro, conforme ocorre no romance (SABINO, 1995, p. 198), o que as faz ir, nas palavras de uma moça oriunda de Montes Claros, para a "puta que o pariu, eu pouco estou me incomodando" (SABINO, 1995, p. 199). A partir de tanta nulidade, consideremos que o espaço do prostíbulo não é necessariamente uma casa e nem a meretriz tem exatamente o estatuto de pessoa humana em nossa sociedade:

Daí a idéia tão corrente, mesmo no Brasil urbano e moderno, da proteção das fronteiras da casa, seja de suas soleiras materiais (quem não está preocupado com o fechamento de suas portas e janelas todas as noites?), seja - principalmente - de suas entradas e saídas morais (DAMATTA, 1998, p. 24).

Que valores morais uma casa de tolerância poderia guardar? Que relações identitárias? Entretanto, se estas mulheres são mulheres, se estão em situação temerária, devem ser apagadas enquanto produtos de consumo? Devem ser portadoras de humanidade, tal como Geraldo Viramundo as considera? 0 fato é que, nesta narrativa, mais do que uma defesa ou uma denúncia das dificuldades vividas em estratos sociais de menor visibilidade, documenta-se o estatuto da mulher na sociedade brasileira:

Assim, se a mulher é da rua, ela deve ser vista e tratada de um modo. Trata-se, para ser mais preciso, das chamadas mulheres da "vida", pois rua e vida formam uma equação importante do nosso sistema de valores (DAMATTA, 1998, p. 30).

Ora, a mulher da rua, essa que é a comida de todos, é algo muito diferente, conforme já assinalei acima. Em contraste com a mãe, a virgem e a boa esposa, ela surge como aquela mulher que pode literalmente causar indigestão nos homens, provocando a sua perturbação moral (DAMATTA, 1998, p. 58). 
Devem as mulheres, evidentemente, ser tratadas como a Marialva (SABINO, 1995, p. 190ss.), isto é, certamente devem ser forçadas a ir aonde o Montalvão quer? Devem apanhar, já que são mulheres da rua? É inquietante que a antropologia brasileira esteja politicamente comprometida com dicotomias tais, de modo a pôr em relevo apenas a "virgem", a mulher "de casa". Provavelmente apenas esta mulher pode ter estatuto de ser humano. É “comida” diferente.

Encetar um discurso literário sobre os que não têm voz é problemático. Deve-se avaliar, em grande medida, o que disse Wilson Martins (1995) sobre a distância entre política e carnavalização; deve-se avaliar, ainda, o fato de que o discurso literário é sempre imaginação, tendendo à ficção. Deixemos claro que o discurso de um literato jamais poderia ser o discurso do próprio marginal. Do ponto de vista artístico, levemos em consideração que uma identidade social, mesmo forjada, literária, satírica, pode não ser o melhor caminho para o engajamento político: a literatura, enfim, não faz a própria luta social.

Em todo caso, se o discurso literário não sai dos gabinetes e das salas de aula de universidades, Geraldo Viramundo foi a Belo Horizonte e acampou na Praça Liberdade, em frente ao Palácio do Governador Ladisbão, junto a retirantes, mulheres (prostitutas), doidos (saídos do hospício de onde Viramundo os libertou) e mendigos. A praça, espaço da rua, tornou-se símbolo do ativismo social:

[...] a rua: o mundo exterior que se mede pela "luta", pela competição e pelo anonimato cruel de individualidades e individualismos. [...] a rua se move sempre num fluxo de pessoas indiferenciadas e desconhecidas que nós chamamos de "povo" e de "massa". [...] O fluxo da vida, com suas contradições, durezas e surpresas, está certamente na rua, onde o tempo é medido pelo relógio e a história se faz acrescentando evento a evento numa cadeia complexa e infinita. [...] Mas aqui, no negro do asfalto, no calor da caminhada para se chegar a algum lugar, no nervosismo do confronto com o policial imbuído de sua autoridade legal, que nos trata como coisas e como indivíduos sem nome nem face, o reino é sinônimo de luta e sangue (DAMATTA, 1998, p. 28-29).

A luta é espaço da luta política. A luta será o espaço do assassinato de Geraldo Viramundo. Após negar a negociação com o Governador: "Saiba o Senhor Governador Geral da 
Província de Minas Gerais que o respeito às normas protocolares, que regem uma tentativa de armistício como esta, me impedem de dizer onde Vossa Excelência deve enfiar esse canudo" (SABINO, 1995, p. 217). As "forças de segurança", então, irromperam na praça e houve "bombas de gás lacrimogêneo e golpes de cassetete a torto e a direito" (SABINO, 1995, p. 218), e logo a multidão de revoltosos estava dispersa. Ao voltar a palmilhar a estrada, logo Geraldo Viramundo estava de volta a Rio Acima, junto com seus companheiros (Capitão Batatinhas e Barbeca). E como eles estavam esfomeados, os dois camaradas saquearam "um pedaço de toicinho, um queijo palmira e um pacote de biscoito de polvilho" (SABINO, 1995, p. 222), e o dono do armazém, Breno Boaventura, para provar que a violência também atinge os civis da mais tenra idade até os adultos, para deixar também evidente que a "surra" que damos ou que permitimos que se dê pode significar ainda o assassinato do nosso próprio irmão, que não reconhecemos porque ele está há muito tempo na estrada. Após a morte a pauladas, tal como um Judas, Geraldo Viramundo morre, com a pontada de uma lança manejada por uma criança. Os amigos tentam lavar o "rosto ensanguentado" dele e só conseguem obter de volta o sorriso de quem já entregara o espírito às violências de todos os dias e de todos os brasileiros.

\section{Considerações Finais}

A violência, no Brasil, ocorre com várias faces. Há a violência física, muitas vezes carregada de questões raciais; há a violência simbólica cruzada: tanto há a violência do manicômio, quanto há a violência dos privilégios; em terceiro lugar, demonstramos como a religião católica conduziu-nos a um reforço violentíssimo sobre o uso do corpo feminino; por último, vimos a representação de outro tipo de violência simbólica, operada em forma de subtração da humanidade das prostitutas.

O Grande Mentecapto (1979), de Fernando Sabino, não inventou tais formas violentas de existência cultural. O Brasil se fez "nação" a partir de tais construtos histórico-sociais, de modo que tais processos sociais são refletidos em corpos negros, loucos e femininos: como já se disse antes, tal como há o corpo que fecha a mão, há os corpos que recebem 
socos e pontapés. De certa forma, o romance escolhido para análise denuncia tais desmandos culturais.

Cabe-nos, em primeiro lugar, através da literatura e das artes em geral, tomarmos consciência dos usos e motivos históricos da violência em nossa cultura. Depois de examinarmos romances como $O$ Grande Mentecapto (1979) e procedermos à leitura de bons autores de História, Sociologia e áreas correlatas, devemos começar a nos perguntar: "essa violência ocorre de maneira igualitária?". Ao percebermos que a nossa Democracia possui certas disfuncionalidades em relação a alguns grupos sociais, poderemos nos organizar simbólica e politicamente.

Com o intuito de encerrarmos o ciclo de xingamentos de "frescura" em relação a homens de diversos comportamentos, apedrejamentos de mulheres que se querem sexualmente livres, surras gratuitas em negros, precisamos ler e compreender a arte. A literatura, através das representações de tais embates culturais, cumpre com tal engajamento. Faltanos, a partir da leitura de $O$ Grande Mentecapto (1979), termos a mesma sábia loucura de Geraldo Viramundo: precisamos começar a nos indignar, junto às prostitutas, aos retirantes, aos loucos, quanto às violências cotidianas produzidas pela elite política e econômica. A Praça da Liberdade precisa deixar de ser apenas um nome e poderá representar uma condição humana possível para que o Brasil deixe de se construir "nação" e passe a se reconhecer, simbolicamente, como Nação. 


\section{Referências}

AMADO, Jorge. O Grande Mentecapto. In: SABINO, Fernando. Obra reunida. Rio de Janeiro: Nova Aguilar, 1996. p. 70-71.

ALENCASTRO, Luiz Felipe de. Índios, os escravos da terra. In: Trato dos viventes: formação do Brasil no Atlântico Sul. São Paulo: Companhia das Letras, 2000. p. 117-154.

CÂNDIDO, Antonio. Dialética da malandragem. In: 0 discurso e a cidade. 3 ed. São Paulo: Ouro sobre Azul, 2004. p. 17-46.

DAMATTA, Roberto. 0 que faz o brasil, Brasil? Rio de Janeiro: Rocco, 1998.

FERNANDES, Florestan. Aspectos da Questão Racial. In: O negro no mundo dos brancos. São Paulo: Global, 2007. p. 38-63.

FREYRE, Gilberto. Casa-grande \& Senzala. São Paulo: Global, 2006.

GONZALEZ, Mario. Romance picaresco: conceito e extensão. In: A saga do antiherói: estudo sobre o romance picaresco espanhol e algumas de suas correspondências na literatura brasileira. São Paulo: Nova Alexandria, 1994. p. 204-269.

HOLANDA, Sérgio Buarque de. O homem cordial. In: Raízes do Brasil. São Paulo: Companhia das Letras, 2013. p. 139-151.

MARTINS, Wilson. Situação do romance. In: Pontos de vista: crítica literária. São Paulo: T. A. Queiroz, 1995. p. 239-244.

ORTIZ, Renato. Da raça à cultura: a mestiçagem e o nacional. In: \& identidade nacional. São Paulo: Brasiliense, 2012. p. 36-44. Cultura brasileira

ROSA, João Guimarães. [1967]. Tutaméia: terceiras estórias. 5. ed. Rio de Janeiro: José Olympio, 1979.

SABINO, Fernando. O Grande Mentecapto: Relato das aventuras e desventuras de Viramundo e de suas inenarráveis peregrinações. 46. ed. Rio de Janeiro: Record, 1995. 236p.

SABINO, Fernando. 0 Encontro Marcado. 64. ed. Rio de Janeiro: Record, 1996. 284p.

WISNIK, José Miguel. Grandes cursos Cultura na TV: Famigerado. Disponível em $<$ http://www.youtube.com/watch?v=5LHhtBf24Nk>. Acesso em 24 de julho de 2013. 